\title{
Tanggung Jawab Direksi Pada Perseroan Terbatas Milik Badan Usaha Milik Negara
}

\author{
Tasya Nailul Fikriya \\ Fakultas Hukum Universitas Islam Indonesia Yogyakarta Indonesia \\ Jln. Cik Di Tiro No. 1 Yogyakarta Indonesia \\ tasyanailulfikriya@gmail.com
}

\begin{abstract}
This study focuses on the responsibilities of the Board of Directors in the event of a financial loss to a limited liability company in the form of State-Owned Enterprises (BUMN). The purpose of this research is to identify two issues, first, the legal responsibility of the company directors in a Limited Liability Company (PT), and second, whether the loss of the management of a Limited Liability Company can be seen as a loss to the State. The method used is normative juridical. The results of the study concluded that the legal responsibility of the company directors in a Limited Liability Company (PT), is based on the principle that each member of the Board of Directors is fully responsible personally for the loss of the Company if the person concerned is guilty or negligent in carrying out his duties. Separation of state assets from the State Revenue and Expenditure Budget (APBN) to be subsequently used as capital in BUMN (company), does not cause a break in the legal relationship between the state and the BUMN, given the state's position as a legal subject that owns shares (majority) in BUMN in the form of a company.
\end{abstract}

Key Words: Board of Directors; BUMN; liability

\begin{abstract}
Abstrak
Kajian ini dititikberatkan pada tanggung jawab direksi dalam hal terjadi kerugian keuangan pada perseroan terbatas milik Badan Usaha Milik Negara (BUMN). Tujuan dalam penelitian untuk mengkaji dua hal, pertama tanggung jawab hukum dari direksi perusahaan pada suatu Perseroan Terbatas (PT), dan kedua, kerugian atas pengelolaan Perseroan Terbatas apakah dapat dipandang sebagai kerugian negara. Metode yang penulis gunakan adalah yuridis normatif. Hasil penelitian menyimpulkan bahwa tanggung jawab hukum dari direksi perusahaan pada suatu Perseroan Terbatas (PT), didasarkan pada prinsip bahwa setiap anggota Direksi bertanggung jawab penuh secara pribadi atas kerugian Perseroan apabila yang bersangkutan bersalah atau lalai dalam menjalankan tugasnya. Pemisahan kekayaan negara dari Anggaran Pendapatan dan Belania Negara (APBN) untuk selanjutnya dijadikan sebagai modal pada BUMN (perseroan), tidak menyebabkan putusnya hubungan hukum antara negara dengan BUMN tersebut, mengingat kedudukan negara sebagai subyek hukum yang memiliki saham (mayoritas) di BUMN berbentuk perseroan.
\end{abstract}

Kata-kata Kunci: BUMN; direksi; tanggungjawab 


\section{Pendahuluan}

Badan Usaha Milik Negara (BUMN) adalah perusahaan yang didirikan dan dikelola oleh negara untuk menjalankan kegiatan operasional di sektor industri dan bisnis strategis. Pemerintah Indonesia mendirikan BUMN dengan dua tujuan utama, yaitu tujuan yang bersifat ekonomi dan tujuan yang bersifat sosial. Dalam tujuan yang bersifat ekonomi, BUMN dimaksudkan untuk mengelola sektorsektor bisnis strategis agar tidak dikuasai pihak-pihak tertentu. Bidang-bidang usaha yang menyangkut hajat hidup orang banyak, seperti perusahaan listrik, minyak dan gas bumi, sebagaimana diamanatkan dalam Pasal 33 UUD 1945, seyogyanya dikuasai oleh BUMN. Tujuan BUMN yang bersifat sosial antara lain dapat dicapai melalui penciptaan lapangan kerja yang dicapai dengan perekruitan tenaga kerja serta upaya untuk membangkitkan perekonomian lokal.

BUMN sebagai salah satu pelaku kegiatan ekonomi dalam perekonomian nasional berdasarkan demokrasi ekonomi mempunyai peranan penting dalam penyelenggaraan perekonomian nasional guna mewujudkan kesejahteraan masyarakat. Kehadiran BUMN merupakan langkah konkrit pemerintah dalam rangka mewujudkan cita-cita bangsa untuk memajukan kesejahteraan umum. Maksud dan tujuan pendirian BUMN tercantum pada Pasal 2 ayat (1) UndangUndang Nomor 19 Tahun 2003 tentang Badan Usaha Milik Negara (BUMN). ${ }^{1}$

Selain itu BUMN juga dapat dikatakan memiliki dua tujuan sekaligus yaitu tujuan yang bersifat komersil dan tujuan yang bersifat sosial. Dalam tujuan bersifat komersil yaitu mengejar keuntungan atau laba, BUMN dituntut agar dapat diselenggarakan secara profesional dalam pelaksanaannya sebagai salah satu sumber keuangan kas negara. Aminuddin Umar mengemukakan bahwa:2

"kemampuan dan kinerja BUMN menjadi tumpuan harapan tidak saja untuk menyelenggarakan fungsi kemanfaatan umum berupa penyediaan barang dan jasa yang bermutu tinggi dan berdaya saling kuat baik di pasar dalam negeri maupun dipasar global, akan tetapi menjadi pendorong bagi sektor ekonomi lainnya untuk bangkit melalui program kemitraan usaha maupun sebagai penghasil laba atau keuntungan bagi negara-negara."

BUMN terdiri atas Perusahaan Persero (Persero) dan Perusahaan Umum (Perum). Persero adalah BUMN yang berbentuk Perseroan Terbatas (PT) yang modalnya terbagi dalam saham yang seluruhnya atau paling sedikit 51\% sahamnya dimiliki oleh Negara Republik Indonesia yang tujuan utamanya mengejar keuntungan. Sedangkan Perum adalah BUMN yang seluruh modalnya

${ }^{1}$ Ridwan Khairandy, Korupsi Kerugian Kenangan Negara di BUMN, FH UII Press, Yogyakarta, 2018, hlm. 1.

2 Amiruddin Ilmar, Privatisasi BUMN di Indonesia, Hasanuddin University Press, Makassar, 2004, hlm. 3. 
dimiliki negara dan tidak terbagi atas saham, yang bertujuan untuk kemanfaatan umum berupa penyediaan barang dan/atau jasa yang bermutu tinggi dan sekaligus mengejar keuntungan berdasarkan prinsip pengelolaan perusahaan.

Secara hukum Perseroan Terbatas merupakan bentuk badan usaha yang dahulu diatur dalam Bagian III dari Buku I Kitab Undang-undang Hukum Dagang (Wetboek van Koophandel voor Nederlandsch Indie) dari Pasal 36 sampai Pasal 56. Saat ini Perseroan Terbatas diatur dalam Undang-Undang Perseroan terbatas (UUPT), yaitu UU Nomor 1 Tahun 1995 yang kemudian diganti dengan Undang-Undang No. 40 Tahun 2007 tentang Perseroan terbatas. Bentuk ini menurut aslinya, sebagaimana ditetapkan dalam Kitab Undang-Undang Hukum Dagang (KUHD) bernama Naamloze Vennootschap disingkat NV. Tidak ada undang-undang yang secara khusus dan resmi memerintahkan untuk mengubah sebutan Naamloze Vennootschap hingga harus disebut sebagai Perseroan Terbatas (PT). Bagaimana asal muasal hingga timbul sebutan Perseroan Terbatas tidak dapat ditemukan, namun sebutan itu telah menjadi baku dalam masyarakat. Bahkan dalam berbagai perundang-undangan nasional kita telah terbiasa dipergunakan. ${ }^{3}$

Maksud dan tujuan pendirian Persero menurut Pasal 12 huruf a dan b UU BUMN adalah menyediakan barang dan/atau jasa yang bermutu tinggi dan berdaya saing kuat; dan mengejar keuntungan guna meningkatkan nilai perusahaan. Adapun maksud dan tujuan Perum menurut Pasal 36 ayat (1) adalah menyelenggarakan usaha yang bertujuan untuk kemanfaatan umum berupa penyediaan barang dan/jasa yang berkualitas dengan harga yang terjangkau oleh masyarakat berdasarkan prinsip pengelolaan perusahaan yang sehat.

Berdasarkan penjelasan di atas, terdapat perbedaan secara mendasar antara maksud dan tujuan Persero dan Perum, yaitu pada orientasinya. Maksud dan tujuan pendirian Persero berorientasi pada keuntungan, sedangkan maksud dan tujuan pendirian Perum lebih berorientasi pada layanan umum sekaligus mengejar keuntungan.

Pada BUMN yang berbentuk persero adalah menjadi tugas bagi seorang direksi memutuskan untuk menjalankan sesuatu yang memberikan hasil maksimal atau signifikan bagi persero. Bisnis adalah risiko, di tengah persaingan ekonomi global yang kompetitif usaha Direksi Persero dalam menggerakkan roda bisnisnya tentu tergantung pada risiko bisnis yang tidak selamanya akan membawa keuntungan namun juga membawa risiko kerugian. Pada saat Persero mengalami kerugian dalam transaksi bisnisnya memunculkan polemik mengenai aturan hukum pertanggungjawaban yang harus dilakukan oleh direksi.

\footnotetext{
${ }^{3}$ Rudhi Prasetya, Kedudukan Mandiri Perseroan Terbatas, PT. Citra Aditya Bakti, Bandung, 1996, hlm. 56.
} 
Terdapat permasalahan hukum pada pengenaan ketentuan tindak pidana korupsi terhadap tindakan direksi yang menyebabkan kerugian keuangan Persero, terlebih lagi jika tindakan direksi berdasarkan atas iktikad baik. Permasalahan tersebut terdapat baik pada sektor hulu, yaitu peraturan maupun pada sektor hilir, yaitu penegakan hukumnya.

Sebagaimana pelaku bisnis pada umumnya, BUMN, khususnya Persero dalam mengejar keuntungan berpotensi mengalami kerugian dalam kegiatan bisnisnya. Kerugian tersebut seringkali dianggap sebagai kerugian keuangan negara yang pada akhirnya dikualifikasikan sebagai tindak pidana korupsi. Pemikiran demikian lahir dari pemaknaan keuangan negara yang sangat luas termasuk sebagai kekayaan negara yang dipisahkan. Hal demikian membawa implikasi terhadap pertanggungjawaban Direksi Persero, ketentuan hukum mana yang seharusnya mengatur, apakah masuk ranah hukum publik ataukah hukum privat. Pemahaman tentang hal ini penting untuk menjamin adanya kepastian hukum, sehingga direksi tidak perlu ragu-ragu lagi dalam mengelola persero yang menjadi tanggungjawabnya, agar dapat fokus mencapai target yang optimum dalam mengejar keuntungan bagi persero sebagaimana diamanatkan dalam Anggaran Dasar dan ketentuan Perundang-undangan.

\section{Rumusan Masalah}

Berdasarkan uraian yang telah dikemukakan di atas, dapat dirumuskan pokok permasalahan dalam penelitian ini yaitu: Pertama, bagaimana tanggung jawab hukum dari direksi perusahaan pada suatu Perseroan Terbatas (PT)? Kedua, bagaimana kerugian atas pengelolaan Perseroan Terbatas dapat dipandang sebagai kerugian Negara?

\section{Tujuan Penelitian}

Adapun tujuan penelitian ini adalah untuk mengetahui: Pertama, tanggung jawab hukum dari direksi perusahaan pada suatu Perseroan Terbatas (PT). Kedua, untuk mengetahui kerugian atas pengelolaan Perseroan Terbatas apakah dapat dipandang sebagai kerugian Negara.

\section{Metode Penelitian}

Penelitian karya ilmiah ini, berjenis penelitian hukum normatif (yuridis normatif), yaitu penelitian yang bertujuan untuk meneliti asas-asas hukum, 
sistematika hukum, sinkronisasi hukum, sejarah hukum dan perbandingan hukum. ${ }^{4}$ Penelitian ini difokuskan untuk mengkaji dan meneliti tanggung jawab direksi dalam hal terjadi kerugian keuangan pada perseroan terbatas milik badan usaha milik negara. Nilai ilmiah suatu pembahasan dan pemecahan masalah terhadap legal issue yang diteliti sangat tergantung kepada cara pendekatan (approach) yang digunakan. ${ }^{5}$ Sesuai dengan tipe penelitian yang digunakan yaitu yuridis normatif, maka pendekatan masalah yang dilakukan adalah, pendekatan perundang-undangan (statute approach). Pendekatan perundang-undangan merupakan suatu hal yang mutlak dalam penelitian yuridis normatif, karena yang akan diteliti adalah berbagai aturan hukum yang menjadi fokus sekaligus tema sentral suatu penelitian. ${ }^{6}$ Pendekatan perundang-undangan dilakukan dengan menelaah semua undang-undang dan regulasi yang bersangkut paut dengan isu hukum yang sedang ditangani. ${ }^{7}$ Tentu tidak semua bidang perundang-undangan yang hendak diteliti, ${ }^{8}$ isu tersebut adalah peraturan yang menyangkut terkait tanggung jawab direksi dalam hal terjadi kerugian keuangan pada perseroan terbatas milik badan usaha milik negara.

\section{Hasil Penelitian dan Pembahasan}

\section{Tanggung Jawab Hukum dari Direksi Perusahaan Pada Suatu Perseroan Terbatas (PT)}

Tanggung jawab berarti keadaan wajib menanggung segala sesuatunya (kalau ada sesuatu hal, boleh dituntut, dipersalahkan, diperkarakan, dan sebagainya). ${ }^{9}$ Dilihat dari sudut pandang manajemen, tanggung jawab adalah kewajiban seseorang individu untuk melaksanakan aktivitas yang ditugaskan kepadanya sebaik mungkin, sesuai dengan kemampuannya. ${ }^{10}$ Sedangkan kaitannya dengan tanggung jawab direksi adalah tanggung jawab dalam mengurus perseroan dan mewakili perseroan baik di dalam maupun diluar pengadilan. Dalam menjalankan tanggung jawab itu, direksi wajib menjalankannya dengan iktikad baik dan penuh rasa tanggung jawab. Apabila dalam menjalankan tugas yang menjadi karyawan direksi menyebabkan perseroan mengalami kerugian, maka direksi dapat diminta pertanggungjawaban.

\footnotetext{
${ }^{4}$ Soerjono Soekanto, Pengantar Penelitian Hukum, Penerbit Universitas Indonesia, Jakarta, 2008, hlm. 52. ${ }^{5}$ Johnny Ibrahim, Teori dan Metodologi Penelitian Hukum Normatif, Bayumedia Publishing, Malang, 2006, hlm. 299.

6 I Made Pasek Diantha, Metodologi Penelitian Hukum Nomatif Dalam Justifikasi Teori Hukum, Kencana, Jakarta, 2016, hlm. 89.

7 Peter Mahmud Marzuki, Penelitian Hukum, Kencana Prenada Media Grup, Jakarta, 2005, hlm. 93.

8 Amirudin dan Zaikin Asikin, Pengantar Metode Penelitian Hukum, Jakarta, Rajawalipress, 2012, hlm. 130.

${ }^{9}$ Ridwan HR, Hukum Administrasi Negara, edisi revisi, Rajagrafindo, Jakarta, 2014, hlm. 318.

${ }^{10}$ Winardi, Asas-asa Manajemen, Alumni, Bandung, 1983, hlm. 5.
} 
Sebagaimana yang telah dikemukakan bahwa tanggung jawab direksi adalah menjalankan perseroan dan mewakili perseroan. Hubungan itu bertumpu pada anggaran dasar RUPS, sesuai dengan Undang-Undang Nomor 40 Tahun 2007 tentang Perseoran Terbatas, peraturan pelaksanaan dan peraturan perundang- undangan lainnya. Pelaksanaan dan tanggung jawab direksi dalam menjalankan perseroan terbatas ini, setidaknya harus memenuhi doktrin atau prinsip perseroan terbatas.

Perusahaan yang berbentuk Perseroan Terbatas, umumnya berorientasi profit, untuk menjaga keberlangsungan dan perkembangan perusahaan. Dengan demikian agar Direksi sebagai organ Perseroan yang mengurus Perseroan sehari-hari, dapat mencapai prestasi terbesar untuk kepentingan Perseroan, maka para Direksi harus diberi kewenangan-kewenangan tertentu untuk melakukan pengelolaan organisasi dan untuk mencapai hasil yang optimal dalam mengurus Perseroan. Melalui kewenangan yang telah diberikan tersebut, Direksi juga perlu diberi tanggung jawab untuk mengurus Perseroan. Hal ini berarti dalam membicarakan kewenangan Direksi, diperlukan pemahaman tentang tanggung-jawabnya.

Berkaitan dengan ketentuan mengenai direksi diatur dari Pasal 15 sampai dengan Pasal 26 BUMN. Ketentuan dalam Pasal ini sebenarnya tidak seluruhnya dapat disebut sebagai ketentuan khusus karena sebagian isi pasal-pasal tersebut hanya pengulangan ketentuan yang ditentukan dalam UU PT.

Pengaturan tentang direksi tidak banyak ditemukan dalam UU BUMN sehingga karena terhadap Persero berlaku segala ketentuan dan prinsip-prinsip yang berlaku bagi PT maka aturan mengenai direksi dapa mengacu pada UU PT.

Direksi dalam melakukan tugasnya berdasarkan kepercayaan, jadi harus berbuat bona fidel,11 untuk kepentingan perseroan secara keseluruhan, dan bukanlah untuk kepentingan para pemegang saham. Lebih jauh ia harus melakukan kegiatan sesuai dengan jalan pikirannya sendiri, apa yang terbaik bagi perseroan, dan bukan apa yang baik menurut pertimbangan pengadilan. Direksi yang memperoleh hak dan dibebani kewajiban untuk memutuskan apa yang penting untuk perseroan, dan bagaimana melaksanakannya berdasarkan pertimbangan praktis, putusannya bila dilakukan dengan iktikad baik dan tujuan yang benar, tidak terbuka bagi pengadilan untuk ditinjau kembali. Pemegang saham pada suatu Rapat Umum Pemegang Saham, memberikan suaranya untuk kepentingan dirinya sendiri, bukan untuk kepentingan perusahaan.

${ }^{11}$ Bona fidel berarti: in or with good faith. 
Direksi sebagai organ yang bertugas dan bertanggung jawab melaksanakan pengurusan perusahaan sangat berpotensi melakukan pelanggaran atau penyimpangan tugas dan kewajiban yang dibebankan kepada direksi. Direksi yang secara sengaja dengan ittikad buruk melakukan perbuatan melawan hukum dengan menggunakan harta kekayaan perseroan untuk kepen ngan pribadinya, sehingga menyebabkan timbulnya kerugian bagi perseroan, maka diterapkan asas piercing the corporate veil yaitu pertanggungjawaban penuh secara pribadi untuk menanggung segala kerugian yang ditimbulkan terhadap perseroan jika direksi terbukti melakukan kesalahan secara pribadi yang menyebabkan timbulnya kerugian bagi perseroan. Pengadilan akan mengesampingkan status badan hukum perseroan tersebut dan membebankan tanggung jawab kepada direksi dengan mengabaikan prinsip tanggung jawab terbatas. Apabila direksi terbukti melakukan kesalahan secara pribadi yang menyebabkan timbulnya kerugian bagi perseroan, maka tidak ada lagi ruang bagi direksi sebagai pengurus perseroan untuk melakukan perbuatan yang dapat menimbulkan kerugian bagi perseroan, pemegang saham, ataupun pihak ketiga.

Direksi berwenang menjalankan pengurusan PT sesuai dengan kebijakan yang dipandang tepat pada batas yang ditentukan dalam UU dan/atau Anggaran Dasar. Hubungan antara direksi dan PT selain didasarkan hubungan kerja juga memiliki hubungan fidusia dengan PT. Direksi memiliki kedudukan fidusia (fiduciary position) di dalam PT. ${ }^{12}$

Seseorang dikatakan memiliki tugas fiduciary (fiduciary duty) manakala ia memiliki kapasitas fiduciary (fiduciary capacity). Seseorang dikatakan memiliki kapasitas fiduciary jika bisnis yang ditransaksinya, harta benda atau kekayaan yang dikuasainya bukan untuk kepentingan dirinya sendiri, tetapi untuk kepentingan orang lain. Orang yang memberinya kewenangan tersebut, memiliki kepercayaan yang besar kepadanya. Pemegang amanah pun wajib memiliki iktikad baik dalam menjalankan tugasnya. ${ }^{13}$

Fiduciary duty direksi akan memberikan perindungan yang berarti bagi pemegang saham dan PT. Hal ini dikarenakan pemegang saham dan PT tidak dapat sepenuhnya melindungi dirinya sendiri dari tindakan direksi yang merugikan di mana direksi bertindak atas nama perusahaan dan pemegang saham. Untuk menghindari adanya penyalahgunaan aset-aset perusahaan dan wewenang oleh direksi maka direksi dibebankan dengan adanya fiduciary duty.

12 Ridwan Khairandy, Hukum Perseroan Terbatas, FH UII Press, Yogyakarta, 2014, hlm. 257.

13 Munir Fuady, Doktrin-Doktrin Modern dalam Corporate Law-Eksistensinya dalam Hukum Indonesia, Citra Aditya Bakti, Bandung, 2002, hlm. 33. 
Fiduciary duty direksi dibagi menjadi dua komponen utama, yaitu duty of care dan duty of loyalty. Duty of care pada dasarnya merupakan kewajiban direksi untuk tidak bertindak lalai, menerapkan ketelitian tingkat tinggi dalam mengumpulkan informasi yang digunakan untuk membuat keputusan bisnis, dan menjalankan manajemen bisnisnya dengan kepedulian dan kehati-hatian yang masuk akal. Duty of loyalty mencakup kewajiban direksi untuk tidak menempatkan kepentingan pribadinya di atas kepentingan perusahaan dalam melakukan transaksi dimana transaksi tersebut dapat menguntungkan direksi dengan menggunakan biaya-biaya yang ditanggung oleh perusahaan atau corporate opportunity.

Fiduciary duty direksi mengandung prinsip-prinsip sebagai berikut: ${ }^{14}$

1. Direksi dalam melakukan tugasnya tidak boleh melakukannya untuk kepentingan pribadi ataupun kepentingan pihak ketiga, tanpa persetujuan dan atau sepengetahuan PT.

2. Direksi tidak boleh memanfaatkan kedudukannya sebagai pengurus untuk memperoleh keuntungan, baik untuk dirinya sendiri maupun pihak ketiga, kecuali atas persetujuan PT; dan

3. Direksi tidak boleh menggunakan atau menyalahgunakan aset PT untuk kepentingannya sendiri dan/atau pihak ketiga.

Pasal 97 ayat (2) UU PT menyebutkan bahwa "pengurusan PT wajib dilaksanakan setiap anggota direksi dengan iktikad baik dan penuh tanggung jawab". Dalam menjalankan tugas fiduciary duties, seorang direksi harus melakukan tugasnya sebagai berikut:

1. Dilakukan dengan iktikad baik

2. Dilakukan dengan proper purpose

3. Dilakukan dengan kebebasan yang bertanggungjawab; dan

4. Tidak memiliki benturan kepentingan (conflict of duty and interest).

Mengenai kerugian yang diderita PT baik pelanggaran fidusia, ultra vires maupun kesalahan lainnya yang dilakukan oleh direksi, pemegang saham PT yang bersangkutan memiliki hak untuk mengajukan gugatan derivatif (derivative action atau derivative suit) terhadap anggota direksi tersebut. Hal ini diatur pada Pasal 97 ayat (6) UU PT yang berbunyi: atas nama PT, pemegang saham yang mewakili paling sedikit $1 / 10$ (satu persepuluh) bagian dari jumlah seluruh saham dengan hak suara dapat mengajukan gugatan melalui pengadilan negeri terhadap anggota direksi yang karena kesalahan atau kelalaiannya menimbulkan kerugian pada PT. dalam penjelasannya disebutkan bahwa "dalam hal tindakan direksi

14 Chatamarrasjid, Penerobosan Cadar Perseroan dan Soal-Soal Aktual Hukum Perusahaan, Citra Aditya, Bandung, 2004, hlm. 196. 
merugikan PT, pemegang saham yang memenuhi persyaratan sebagaimana ditetapkan pada ayat ini dapat mewakili PT untuk melakukan tuntutan atau gugatan terhadap direksi melalui pengadilan.

Mengenai pertanggungjawaban pidana, Pasal 155 UU PT menyebutkan bahwa "ketentuan mengenai tanggung jawab direksi dan/atau dewan komisaris atas kesalahan dan kelalaiannya yang diatur dalam undang-undang ini tidak mengurangi ketentuan yang diatur dalam undang-undang tentang hukum pidana. Ketentuan dalam UU Tipikor yang dapat digunakan untuk menjerat direksi Persero adalah Pasal 8.

Ukuran objekif untuk menentukan perbuatan atau keputusan direksi PT adalah kalkulasi menurut bisnis yaitu menggunakan business judgment rule yang telah dipostifkan pada Pasal 97 UU PT yaitu keputusan bisnis harus diambil dengan iktikad baik, dengan tanggung jawab dan diambil untuk kepentingan PT.

Pasal 97 ayat (5) UU PT berbunyi: anggota direksi tidak dapat dipertanggungjawabkan atas kerugian sebagaimana dimaksud pada ayat (3) apabila dapat membuktikan:

a. Kerugian tersebut bukan karena kesalahan atau kelalaiannya

b. Telah melakukan pengurusan dengan iktikad baik dan kehati-hatian untuk kepentingan dan sesuai dengan maksud dan tujuan PT

c. Tidak mempunyai benturan kepentingan baik langsung maupun tidak langsung atas tindakan pengurusan yang mengakibatkan kerugian; dan

d. Telah mengambil tindakan untuk mencegah timbul atau berlanjutnya kerugian tersebut.

Makna iktikad baik dalam konteks pelaksanaan pengurusan PT oleh anggota direksi dalam praktik dan doktrin hukum, memiliki jangkauan yang luas, antara lain sebagai berikut:

a. Wajib dipercaya (fiduciary duty)

b. Wajib melaksanakan pengurusan untuk tujuan yang wajar (duty to act for a proper purpose)

c. Wajib patuh menaati peraturan perundang-undangan (statutory duty)

d. Wajib loyal terhadap PT (loyalty duty)

e. Wajib menghindari benturan kepentingan (avoid conflict of interest)

\section{Kerugian atas Pengelolaan Perusahaan Badan Usaha Milik Negara (BUMN) Persero Versus Kerugian Negara}

Pengelolaan terhadap suatu perusahaan membutuhkan kerja keras, kerja cerdas dan profesionalisme dalam pengelolaan usaha agar perusahaan dapat maju, berkembang dan terhindar dari risiko kerugian atau kebangkrutan/ kepailitan dalam usaha. Hal ini juga berlaku, terhadap usaha- usaha pada Perusahaan BUMN 
Persero. Sebagaimana yang terdapat dalam Pasal 1 angka 1 UUPT, perseroan terbatas merupakan badan hukum yang merupakan persekutuan modal. Dengan demikian Persero yang dalam pengaturannya merujuk pada UUPT, juga merupakan badan hukum. R. Subekti menjelaskan antara lain ${ }^{15}$, badan hukum merupakan subyek hukum layaknya perorangan yang dapat memiliki hak-hak dan melakukan perbuatan-perbuatan hukum layaknya manusia. Mengenai pengelolaan terhadap usaha-usaha pada Perusahaan BUMN Persero memiliki kinerja yang berbeda-beda antara satu perseroan dengan perseroan lainnya, yang berakibat berbedanya pencapaian laba/rugi masing-masing perusahaan.

Potensi untuk melakukan penyimpangan pada perusahaan BUMN (Persero) masih besar, hal ini seperti yang disampaikan oleh Wakil Ketua Badan Pemeriksa Keuangan Hasan Bisri, yang mengaku khawatir praktek manipulasi dan rekayasa yang dilakukan sejumlah BUMN pada periode 1998-1999 berpotensi terulang. Perkiraan ini timbul terutama apabila uji materi terhadap Undang-Undang Nomor 17 Tahun 2003 tentang Keuangan Negara dan Undang-Undang Nomor 15 Tahun 2006 tentang Badan Pemeriksa Keuangan terkait dengan Undang-Undang Dasar Tahun 1945 dikabulkan oleh Mahkamah Konstitusi.

Kajian secara yuridis pengelolaan terhadap usaha-usaha pada Perusahaan BUMN Persero, dapat dilihat sebagai pengelolaan terhadap suatu Badan Hukum (Rechts Person), yang merupakan buatan manusia. Adapun yang mendorong terbentuknya suatu pengertian badan hukum adalah manusia di dalam hubunganhubungan hukum privat tidak hanya hubungannya dengan sesamanya saja, tetapi juga terhadap persekutuan. Jadi apabila beberapa orang mengadakan kerjasama dan atas dasar ini merupakan kesatuan, maka kesatuan ini merupakan badan hukum setelah memenuhi syarat-syarat yang ditentukan oleh hukum. Dalam melaksanakan hak dan kewajibannya badan hukum diwakili oleh direksinya atau pegawainya. Akan tetapi orang yang bertindak itu tidak untuk dirinya melainkan untuk dan atas pertanggungan gugat badan hukum. Adapun yang dimaksud dengan perikatan (Verbintenis) adalah: Suatu hubungan hukum antara dua orang atau lebih mengenai kekayaan harta benda, yang memberi hak pada yang satu untuk menuntut barang sesuatu dari yang lainnya ini diwajibkan memenuhi tuntutan itu. Pasal 1234 Kitab Undang-Undang Hukum Perdata menentukan bahwa prestasi dapat berupa memberikan sesuatu, berbuat sesuatu dan tidak berbuat sesuatu.

Pada penjelasan Undang-undang Kepailitan, diuraikan pokok-pokok penyempurnaan terhadap Faiilissementsverordening. Pokok-pokok itu meliputi

${ }^{15}$ R. Subekti, Pokok-Pokok Hukum Perdata, Intermasa, Jakarta, 1989, hlm. 21. 
segi-segi penting yang dinilai perlu untuk mewujudkan penyelesaian masalah utang-piutang secara cepat, adil, terbuka dan efektif, yaitu :

a. Penyempurnaan di sekitar syarat-syarat dan prosedur permintaan pernyataan kepailitan. Termasuk di dalamnya, pemberian kerangka waktu yang pasti bagi pengambilan putusan pernyataan kepailitan dll.

b. Penegasan fungsi kurator dan penyempurnaan yang memungkinkan berfungsinya pemberian jasa-jasa tersebut di samping institusi yang selama ini telah dikenal, yaitu Balai Harta Peninggalan.

c. Penegasan upaya hukum yang dapat diambil terhadap putusan pernyataan kepailitan, bahwa untuk itu dapat langsung diajukan kasasi ke Mahkamah Agung.

Dalam rangka kelancaran proses kepailitan dan pengamanan berbagai kepentingan secara adil, dalam rangka penyempurnaan ini juga ditegaskan adanya mekanisme penangguhan pelaksanaan hak di antara kreditor yang memegang hak tanggungan, gadai atau agunan lainnya. Penyempurnaan dilakukan pula terhadap ketentuan tentang penundaan kewajiban pembayaran sebagaimana telah diatur dalam Bab Kedua Undang-undang Kepailitan.

Penegasan dan pembentukan peradilan khusus yang akan menyelesaikan masalah kepailitan secara umum. Pembentukan Pengadilan Niaga ini bukan merupakan langkah diferensiasi atas Peradilan Umum, yang dimungkinkan pembentukannya berdasarkan Undang-Undang No. 14 Tahun 1970 tentang Pokok-pokok Kekuasaan Kehakiman. ${ }^{16}$ Mengenai Pengadilan Niaga, dapat dikemukakan bahwa Pengadilan Niaga bukan merupakan badan peradilan baru di luar badan-badan peradilan yang telah ditetapkan oleh Undang-Undang No. 14 Tahun 1970 tersebut, tetapi sekedar hanya merupakan chamber khusus yang baru dalam Peradilan Umum.

Apabila kewajiban dalam transaksi tersebut masih ada misalnya belum dibayar atau masih ada kekurangan pembayaran, namun perseroan mengalami pembubaran. Maka, bubarnya perseroan tidak boleh merugikan pihak ketiga yang kedudukannya sebagai kreditur. Hal ini dalam hubungannya dengan ketentuan Pasal 1339 ayat (3) KUH Perdata tentang iktikad baik dalam melaksanakan perjanjian. Oleh karena itu, perseroan yang bubar tetap berkewajiban memenuhi pembayaran terhadap pihak kreditur. Untuk dapat memenuhi kewajiban tersebut dilakukan dengan cara likuidasi sebagaimana dimaksud dalam Pasal 115 ayat (4) UUPT, Pasal 116 ayat (5) UUPT dan Pasal 117 ayat (2) UUPT.

Akibat bubarnya perseroan, maka Direksi sejak saat itu tidak berwenang melakukan perbuatan hukum lagi seperti mengadakan transaksi tersebut di atas,

${ }^{16}$ E. Suherman, Faillissement (Kepailitan), Bina Cipta, Bandung, 1988, hlm. 89. 
perbuatan hukum dalam rangka likuidasi dilakukan oleh likuidator. Pertanggungjawaban likuidator sesuai dengan Pasal 124 ayat (1) UUPT diberikan kepada RUPS. Dalam hal terjadinya pembubaran Perseroan Terbatas, terdapat beberapa penyebab yaitu sebagai berikut:

a. Bubarnya Perseroan Terbatas karena keputusan RUPS.

b. Bubarnya Perseroan Terbatas karena jangka waktunya berakhir

c. Bubarnya Perseroan Karena Penetapan Pengadilan

d. Anggaran Dasar berlaku sampai dengan selesainya likuidasi

e. Tindakan Pemberesan Kekayaan

f. KewajibanAdministrasi Likuidator

g. Sikap Kreditur Yang Ditolak Tagihannya

h. Upaya Terhadap Likuidator Yang Melalaikan Tugas

i. Tanggung Jawab Likuidator Atas Likuidasi Yang Dilakukan

j. Bedanya Dengan Perseroan Yang Usahanya Sebagai Bank

Pengelolaan suatu perseroan tidak akan terlepas dari suatu risiko, termasuk risiko kerugian dalam usaha, serta risiko terjadinya kepailitan terhadap perseroan, atau dipailitkannya perseroan pada suatu Pengadilan Niaga oleh pihak ketiga. Dalam hal kepailitan terjadi karena kesalahan atau kelalaian Direksi dan harta pailit tidak cukup untuk membayar seluruh kewajiban Perseroan dalam kepailitan tersebut, maka Pasal 104 ayat (2) UUPT mengatur bahwa setiap anggota Direksi secara tanggung-renteng bertanggung jawab atas seluruh kewajiban yang tidak terlunasi dari harta pailit tersebut. Tanggung jawab yang dimaksud diatas, berlaku juga bagi Direksi yang salah atau lalai yang pernah menjabat sebagai anggota Direksi dalam jangka waktu 5 tahun sebelum putusan pernyataan pailit diucapkan.

Ditinjau dari sudut keuangan, sebenarnya Putusan MK Nomor: 62/PUUXI/2013 adalah tepat bagi BUMN berbentuk Perum, dengan mempertimbangkan aspek kepemilikan, tujuan, dan ketentuan yang mengikat. Ditinjau dari ketiga aspek ini, tidak ada alasan yang kuat untuk memisahkan secara tegas antara BUMN jenis Perum dan negara dari segi keuangan. Namun, hal ini menjadi berbeda bagi BUMN berbentuk persero jika ditinjau dari aspek kepemilikan, tujuan, dan ketentuan yang mengikat. Dalam Pasal 1 angka (2) UU BUMN dinyatakan: "Perusahaan Perseroan yang selanjutnya disebut Persero, adalah BUMN yang berbentuk perseroan terbatas yang modalnya terbagi dalam saham yang seluruhnya atau paling sedikit 51\% sahamnya dimiliki oleh Negara Republik Indonesia yang tujuan utamanya mengejar keuntungan."

Pengertian dalam Pasal 1 angka (2) UU BUMN diatas, menunjukan penekanan pengertian BUMN berbentuk Perseroan adalah pada aspek 
kepemilikannya, yakni minimal $51 \%$ atau bahkan seluruhnya (100\%) saham dimiliki oleh negara. Di sisi lain pengertian ini membuka kemungkinan adanya kepemilikan selain negara terhadap BUMN berbentuk Perseroan. Dengan demikian, dari prespektif kepemilikan BUMN berbentuk Perseoran dapat dianggap sebagai badan usaha milik publik yang didalamnya dimungkinkan terdapat atau yang didalamnya terdapat milik privat.

Mahkamah Konstitusi sendiri memberikan tafsir kepada BUMN dengan menyebutnya sebagai badan yang berbeda dari organ/ lembaga negara disatu sisi, dan berbeda pula dengan badan hukum privat di sisi yang lain. Tafsiran ini memang tidak terlalu jelas, mungkin yang dimaksud adalah quasi badan hukum publik dan badan hukum privat. Tafsiran ini memiliki dua kemungkinan pengertian, yakni badan hukum publik yang didalamnya terdapat unsur privat, atau badan hukum privat yang dimiliki oleh publik. Akan tetapi, jika melihat pengertian BUMN dalam Pasal 1 angka (1) dan (2) UU BUMN, adalah lebih tepat melihat BUMN berbentuk Perseroan sebagai badan hukum privat yang dimiliki publik (Negara). Pengertian ini merupakan konsekuensi logis dari penekanan pengertian BUMN berbentuk perseroan pada aspek kepemilikan saham mayoritas oleh negara. ${ }^{17}$

Hak penguasaan oleh negara dalam konteks kepemilikan BUMN berbentuk perseroan diartikan sebagai penguasaan terhadap mayoritas saham Perseroan. Pengertian berupa penekanan pada kepemilikan saham mayoritas, tidak mengurangi ataupun mengubah kedudukan Perseroan sebagai badan hukum privat. Hal ini sejalan dengan pendapat Mahkamah Konstitusi tentang pengertian BUMN dalam Putusan Nomor: 62/PUU-XI/2013.

Dalam kedudukannya sebagai badan hukum privat yang dipunyai oleh negara, maka BUMN berbentuk perseroan memiliki keuangan sendiri yang terpisah dari keuangan negara. Keuangan tersebut dapat bersumber dari APBN, kapitalisasi cadangan, dan sumber lainya. Yang dimaksud dipisahkan adalah pemisahan kekayaan negara dari APBN untuk selanjutnya pembinaan dan pengelolaannya tidak lagi didasarkan pada sistem APBN, melainkan pada prinsip-prinsip perusahaan yang sehat. ${ }^{18}$

Dari segi kepemilikan, uang atau dana yang dipisahkan pada perusahaanperusahaan, baik perusahaan milik negara mapun swasta, adalah uang atau dana milik negara. ${ }^{19}$ Ketika negara memisahkan kekayaanya pada BUMN, pada

\footnotetext{
17 Dodik Setiawan Nur Heriyanto, "Contracting Out Public Services to NGO Practices in Asian Countries", Public Goods and Governance, Vol.1., No.1., 2016, hlm. 32-34.

${ }_{18}$ Mulhadi, Hukum Perusahaan, Bentuk-Bentuk Badan Usaba di Indonesia, Ghalia Indonesia, Bogor, 2010, hlm. 164.

19 Jimly Asshiddigie, Pokok-Pokok Hukum Tata Negara Indonesia Pasca Reformasi, Bhuana Ilmu Populer, Jakarta, 2007, hlm. 821.
} 
mulanya negara memiliki hak dan kewajiban terhadap sejumlah uang yang dimilikinya. Ketika uang tersebut dipisahkan untuk ditempatkan sebagai modal pada Perseroan, maka hak dan kewajiban terhadap uang tersebut, bertransformasi menjadi hak dan kewajiban yang tertuang dalam kepemilikan saham. Transformasi hak dan kewajiban tersebut sebagai konsekuensi dari dibentuknya subyek hukum yang juga membutuhkan hak dan kewajiban tersendiri. Jadi pendekatan yang lebih tepat dalam melihat pemisahan kekayaan, adalah transformasi hak dan kewajiban yang telah diterima secara universal, dan bukan peralihan hak dan kewajiban seperti dalam prespektif transaksi yang digunakan oleh MK dalam Putusan Nomor: 62/PUU-XI/2013.

Hal ini berlaku sebaliknya ketika badan hukum menyetor bagian laba usahanya. Uang yang semula merupakan uang milik badan hukum, berubah menjadi uang milik pemegang saham. Dalam konteks BUMN berbentuk Perseroan, ketika BUMN menyetor bagian laba usahanya atau pajaknya, uang yang semula merupakan milik privat (keuangan BUMN) berubah menjadi uang milik publik (keuangan negara). ${ }^{20}$

\section{Penutup}

Tanggung jawab hukum dari direksi perusahaan pada suatu Perseroan Terbatas, didasarkan pada prinsip bahwa setiap anggota Direksi bertanggung jawab penuh secara pribadi atas kerugian Perseroan apabila yang bersangkutan bersalah atau lalai dalam menjalankan tugasnya. Apabila Direksi terdiri dari atas 2 anggota Direksi atau lebih, tanggung jawab sebagaimana dimaksud, berlaku secara tanggung renteng bagi setiap anggota Direksi. Anggota Direksi tidak dapat dipertangungjawabkan atas kerugian, apabila dapat membuktikan bahwa: (a). Kerugian tersebut bukan karena kesalahan atau kelalaiannya; (b). Telah melakukan pengurusan dengan iktikad baik dan kehati-hatian untuk kepentingan dan sesuai dengan maksud dan tujuan Perseroan; (c). Tidak mempunyai benturan kepentingan baik langsung maupun tidak langsung atas tindakan pengurusan yang mengakibatkan kerugian; (d). Telah mengambil tindakan untuk mencegah timbul atau berlanjutnya kerugian tersebut.

Pemisahan kekayaan negara dari APBN untuk selanjutnya dijadikan sebagai modal pada BUMN (perseroan), tidak menyebabkan putusnya hubungan hukum antara negara dengan BUMN tersebut, mengingat kedudukan negara sebagai subyek hukum yang memiliki saham (mayoritas) di BUMN berbentuk perseroan.

20 Arifin P. Soeria Atmadja, Keuangan Publik Dalam Prespektif Hukum: Teori, Praktik, dan Kritik, Raja Grafindo, Jakarta, 2010, hlm. 117. 


\section{Daftar Pustaka}

Amirudin dan Zaikin Asikin, Pengantar Metode Penelitian Hukum, Rajawalipress, Jakarta, 2012.

Asshiddigie, Jimly, Pokok-Pokok Hukum Tata Negara Indonesia Pasca Reformasi, Ilmu Populer, Jakarta, 2007.

Chatamarrasjid, Penerobosan Cadar Perseroan dan Soal-Soal Aktual Hukum Perusahaan, Citra Aditya, Bandung, 2004.

Fuady, Munir, Doktrin-Doktrin Modern dalam Corporate Law-Eksistensinya dalam Hukum Indonesia, Citra Aditya Bakti, Bandung, 2002.

Heriyanto, Dodik Setiawan Nur, "Contracting Out Public Services to NGO Practices in Asian Countries", Public Goods and Governance, Vol. 1, No. 1, 2016.

HR, Ridwan, Hukum Administrasi Negara, edisi revisi, Rajagrafindo, Jakarta, 2014.

Ibrahim, Johnny, Teori dan Metodologi Penelitian Hukum Normatif, Bayumedia Publishing, Malang, 2006.

Ilmar, Amiruddin, Privatisasi BUMN di Indonesia, Hasanuddin University Press, Makassar, 2004.

Khairandy, Ridwan, Hukum Perseroan Terbatas, FH UII Press, Yogyakarta, 2014. Korupsi Kerugian Keuangan Negara di BUMN, FH UII Press, Yogyakarta, 2018.

Made, I Pasek Diantha, Metodologi Penelitian Hukum Nomatif Dalam Justifikasi Teori Hukum, Kencana, Jakarta, 2016.

Mahmud, Peter Marzuki, Penelitian Hukum, Kencana Prenada Media Grup, Jakarta, 2005.

Mulhadi, Hukum Perusahaan, Bentuk-Bentuk Badan Usaha di Indonesia, Ghalia Indonesia, Bogor, 2010.

P. Arifin, Soeria Atmadja, Keuangan Publik Dalam Prespektif Hukum: Teori, Praktik, dan Kritik, Raja Grafindo, Jakarta, 2010.

Prasetya, Rudhi, Kedudukan Mandiri Perseroan Terbatas, PT. Citra Aditya Bakti, Bandung, 1996.

Soekanto, Soerjono, Pengantar Penelitian Hukum, Penerbit Universitas Indonesia, Jakarta, 2008.

Subekti, R, Pokok-Pokok Hukum Perdata, Intermasa, Jakarta, 1989.

Suherman, E., Faillissement (Kepailitan), Bina Cipta, Bandung, 1988.

Winardi, Asas-asa Manajemen, Alumni, Bandung, 1983. 